\title{
Concepts and Misconceptions of Humic Substances as the Stable Part of Soil Organic Matter: A Review
}

\author{
Jörg Gerke
}

Ausbau 5, 18258 Rukieten, Germany; gerke.rukieten@t-online.de; Tel.: +49-384-532-0400

Received: 3 March 2018; Accepted: 15 May 2018; Published: 17 May 2018

\begin{abstract}
In the last three decades, the concept of soil humic substances has been questioned in two main directions. Misinterpretations of $\mathrm{CP}$ MAS ${ }^{13} \mathrm{C}$ NMR spectroscopy led to the conclusion that soil organic matter is mainly aliphatic, questioning the theory of polymerization of humic substances from phenolic molecules. Conversely, some critics of humic substances assume that a great proportion of aromatic soil organic carbon originates from fire-affected carbon, often termed as black carbon (BC). However, the determination of $\mathrm{BC}$ in soil by two widely applied methods, the benzene polycarboxylic acid marker method and the UV method, is not reliable and seems to strongly overestimate the BC content of soils. The concept of humic substances continues to be relevant today. The polymerization of phenolic molecules that originate from the degradation of lignin or synthesis by microorganisms may lead to humic substances which can incorporate a variety of organic and inorganic molecules and elements. The incorporation, e.g., of triazines or surfactants into the humic matrix, leading to bound residues, illustrates that humic substances are important to explain central reactions in soil. Humic substances are also important to understand the availability of plant nutrients in soil, including $\mathrm{P}, \mathrm{Fe}$, and $\mathrm{Cu}$, and they may have a direct effect on the growth of higher plants in soil. Therefore, there are good reasons to reformulate or to further develop the concepts and models of humic substances introduced and developed by M. Schnitzer, W. Flaig, W. Ziechmann, and F.J. Stevenson.
\end{abstract}

Keywords: polymerization; phenolic molecules; humification; aromatic humic core; supramolecular structure; black carbon overestimation; misinterpretation of quantitative ${ }^{13} \mathrm{C}$ NMR spectroscopy

\section{Introduction}

For a long time, humic substances were considered as the stable part of soil organic matter with a yellow to dark brown color. This is in fact a central characteristic of this group of soil organic substances, indicating aromatic systems.

Over the decades, this concept has been developed by soil chemists and is summarized, e.g., by Schnitzer [1,2], Flaig et al. [3], Ziechmann [4], Aiken et al. [5], Stevenson [6], and others.

According to the concept of humic substances, its stability is based on two mechanisms: its resistance to microbial attack due to its aromatic cores and the reaction of the soil humic substances with mineral surfaces, which reduces microbial degradability.

The recalcitrance and the affinity of humic substances to mineral surfaces can be explained by the aid of the chemistry of humic substances in soil.

In the beginning of the 1980s, a relatively new, direct, non-destructive, and quantitative spectroscopic method was introduced to soil organic matter research, solid state cross polarization magic angle spinning ${ }^{13} \mathrm{C}$ nuclear magnetic resonance spectroscopy (CPMAS ${ }^{13} \mathrm{C}$ NMR spectroscopy). This method allowed new aspects of research in organic soil chemistry and has been extensively used to quantify the proportions of functional groups as well as the aliphatic and aromatic contents of soil organic matter and humic substances. 
In an early review, Hatcher et al. [7] stated that the CP MAS technique provides a quantitative measure of aromatic, paraffinic, carboxylic acids, and other groups in fulvic acids (FA) and humic acids (HA).

However, this statement by Hatcher et al. [7] on the quantification of the chemical composition of FA or HA by CP MAS spectroscopy was misleading and wrong. For example, the quantification of aromatic carbon using this method was soon proved to fail. Hasselmann [8] stated in his PhD thesis ([8], p. 71) concerning CP MAS ${ }^{13} \mathrm{C}$ NMR spectroscopy that ether-, sugar-, and carboxylate-C are overestimated by this method, whereas aromatic- and chinoid-C are strongly underestimated (translation from German to English by J.G.).

\section{The Quantitative Use of ${ }^{13} \mathrm{C}$ NMR Spectroscopy in Soil Organic Matter Research}

The long time use of ${ }^{13} \mathrm{C}$ NMR spectroscopy in soil chemistry mainly in the CP MAS mode was critically examined by three groups in 2000 [9-12].

These groups findings on the low aromaticity of soil organic matter (among many others $[7,13,14])$, which were obtained with the use of CP MAS ${ }^{13} \mathrm{C}$ NMR spectroscopy.

It took about two decades to check the accuracy of these findings achieved using the $\mathrm{CP}$ MAS technique by using Bloch decay (BD) or direct polarization (DP) ${ }^{13} \mathrm{C}$ NMR spectroscopy as a reference method.

Smernik and Oades [9] compared BD and CP MAS ${ }^{13} \mathrm{C}$ NMR spectroscopy for an Aldrich humic acid (commercial available) and found in the spectra an observable proportion of organic carbon of $35 \%$ and $79 \%$ for CP MAS and BD spectra, respectively. With CP MAS spectroscopy, $65 \%$ of the organic carbon was ignored, mainly aromatic and carbonyl C, whereas with the aid of BD spectroscopy about $80 \%$ of the organic carbon was observed. The results of Smernik and Oades proved that CP MAS ${ }^{13} \mathrm{C}$ NMR spectroscopy is not an acceptable method to quantitatively determine soil organic matter compounds. Mao et al. [10] found with the aid of DP ${ }^{13} \mathrm{C}$ NMR spectroscopy that the content of aromatic carbons in humic substances ranged between 33 and $55 \%$ for different sources, underlining the relevance of aromatic units to the chemical structure of humic substances. Mao et al. [10] stated that "the erroneously low CO content and reduced $\mathrm{sp}^{2}$ to $\mathrm{sp}^{3}$ carbon ratio have led to incorrect conclusions such as statements that humic acids are predominantly aliphatic. Our results show the necessity of significant revision of data and models that used previous CP MAS NMR results quantitatively."

Modifications of the CP MAS procedure, as proposed by Peerson et al. [15] and Cook et al. [16], cannot correct the problems of CP MAS spectroscopy [10]. Today, CP MAS ${ }^{13}$ C NMR spectroscopy is at best a semi-quantitative method [17].

Despite the fundamental criticism of the quantitative use of $\mathrm{CP} M A S^{13} \mathrm{C}$ NMR spectroscopy, this spectroscopic method is still used in quantitative soil organic matter research $[14,18,19]$.

\section{The Concept of Humic Substances in Soil Organic Matter Research}

After the work of Achard, de Saussure, Berzelius, and especially Sprengel in the beginning of the 19th century (see for the history [6], pp. 24 f.), the concept of soil humic substances was fully developed in the second half of the 20th century.

The main basic assumption within the framework of "humic substances" is that degradation products of plant residues and soil microorganisms are partly used to build up new molecules by chemical, biochemical, or biological pathways. These molecules are humic substances.

The chemical and biochemical reactions that are involved were described in detail by Schnitzer [1], Flaig et al. [3], and Ziechmann [4], and were also summarized by Stevenson ([6], pp. 188-210).

The reaction concepts explain the synthesis of humic substances as polymerization processes of phenolic molecules. The phenols initially originate from the degradation of lignin to phenylpropene units and its further reactions $([3,6]$ chapter 8$)$, as well as the microbial synthesis of phenolic substances as described, e.g., by Haider and Martin [20]. 
Aromatic molecules such as polyphenols are characterized by rings with conjugated pi-electrons which allow the delocalization of electrons and the formation of radicals (molecules with free, unpaired electrons).

Ziechmann ([4], p. 142) showed for p-dihydroxyphenol, hydroquinone the formation of mesomeric forms of radicals (Figure 1).
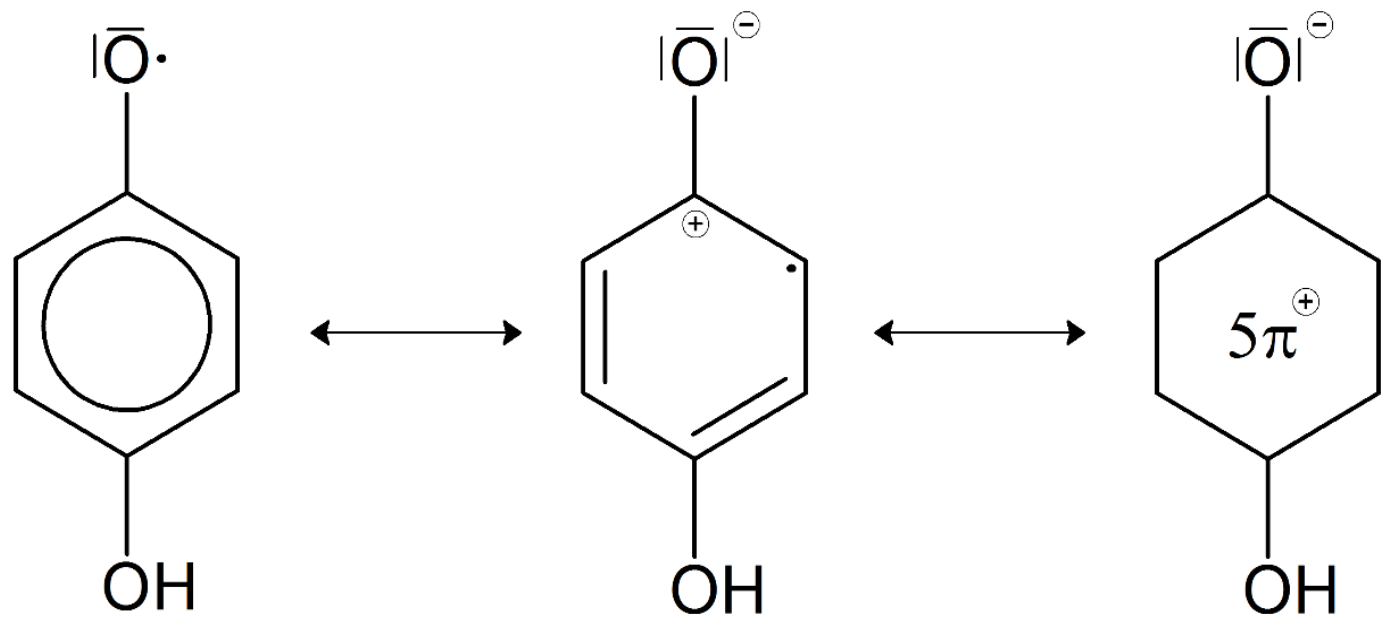

Figure 1. Intramolecular mesomeric structures of hydroquinone according to Ziechmann, 1980, p. 142.

The different mesomeric forms of hydroquinone radicals allow for the formation of various unregular types of -C-O-C- and -C-C- bonding within the polymerization reaction products. In alkaline solution, hydroquinone reacts by the formation of high molecular weight aromatic and brown reaction products. Catechol, o-dihydroxyphenol, also forms such brown and high molecular weight reaction products in alkaline solution, whereas resorcinol, i.e., m-dihydroxyphenol, does not polymerize in alkaline solution.

Flaig et al. [3] showed several pathways by which the polymerization of phenylpropene units resulting from the degradation of lignin may occur. They showed that if $\mathrm{OH}$ - groups in p-position within the phenol ring were methylated, the phenols do not polymerize to humic-like products. This is also in accordance with the concept of humic formation presented by Ziechmann [4].

Weichelt [21] showed that more or less unaltered lignin interacted with humic-like polymers from pyrogallol and was chemically incorporated into the humic framework.

Haider et al. [22] also showed that some fungal melanins were similar to soil humic acids as evaluated by pyrolysis mass spectrometry.

The incorporation of nitrogen $(\mathrm{N})$ into humic polymers by the formation of $-\mathrm{C}-\mathrm{N}-\mathrm{C}-$ or $-\mathrm{C}=\mathrm{N}-\mathrm{C}-$ bonds ([4], p. 143) probably leads to a $\mathrm{N}$-fraction of soil organic matter which cannot be hydrolyzed by hot $6 \mathrm{M} \mathrm{HCl}$ and is known as acid insoluble $\mathrm{N}$ ([6], chapter 3).

Additionally, an $\mathrm{OH}$ radical can easily react with phenols, as shown in Figure 2.

The reaction in Figure 2 allows further polymerization reactions, creating a three-dimensional net of aromatic cores and thus building the center of humic substances in soil.

These cores can further react with other molecules, such as amino acids, peptides, sugars polysaccharides, and others.

Stevenson ([6], p. 205) described this incorporation in the case of the reaction of catechol and glycine, essential amino acids which are incorporated or form nitrogenous brown polymers/humic substances (Figure 3). 

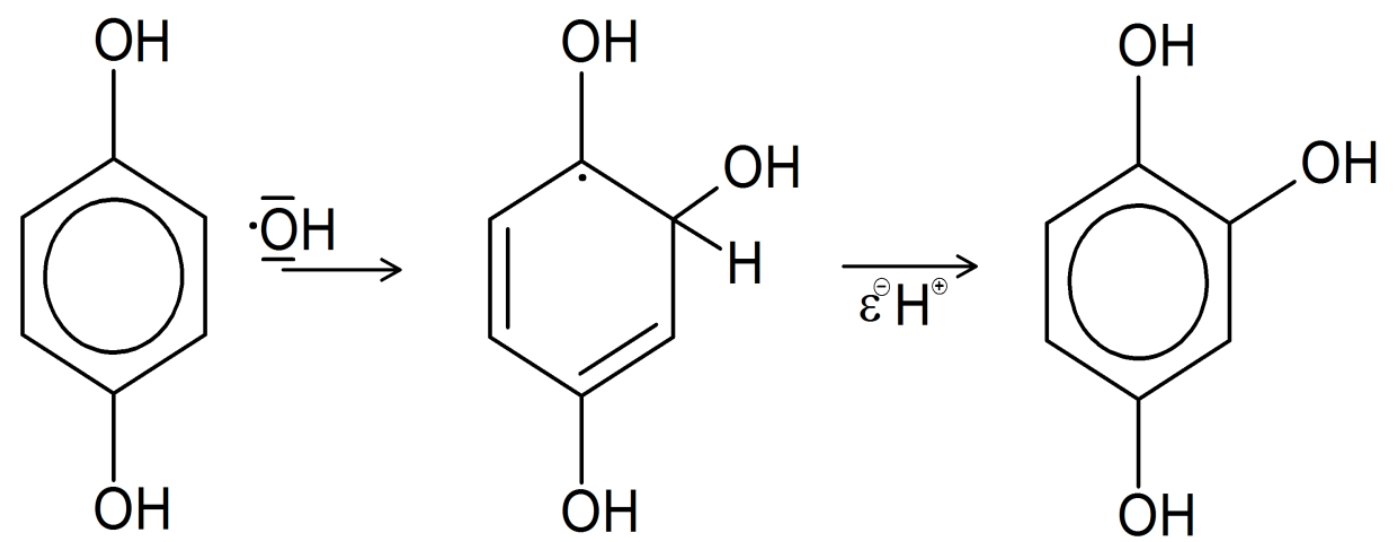

Figure 2. Introduction of a third OH- group into hydroquinone (Ziechmann, 1980, p. 149).<smiles>CC(C)CNCC(=O)O</smiles><smiles>NCC(=O)CCNC1=CC(O)C(=O)C=C1</smiles><smiles>O=C(O)CN=C1C=C(NCC(=O)O)C=CC1=O</smiles><smiles>O=C(O)CN=C1C=C(NCC(=O)O)C=CC1=O</smiles><smiles>O=C(O)C=Nc1cc(NCC(=O)O)ccc1O</smiles><smiles>Nc1cc(NCC(=O)O)ccc1O</smiles><smiles>O=C(O)CNC1=CC(=O)C(=O)C=C1</smiles><smiles>Nc1cc(NCC(=O)O)ccc1O</smiles>

Figure 3. Formation of humic substances from catechol and glycine (after Stevenson [6], modified).

The reactions involved in the formation of humic substances require the formation of radicals of phenols and their polymerization. Soil microorganisms may also be able to synthesize humic acid like polymers [20]. The continuous delivery of polyphenols by the degradation of lignin 
molecules and by microbial synthesis is one precondition for the formation of humic substances. The subsequent formation of radicals and their polymerization may be catalyzed by exoenzymes such as oxidoreductases or phenoloxidases, as shown by Martin et al. [23]. Piccolo et al. [24] and Cozzolini and Piccolo [25] transferred the supramolecular structure of humic substances into a covalently linked polymer by treating it with peroxidase. Other catalysts for the formation of humic polymers are Fe and Mn on mineral surfaces, as shown by Wang et al. [26-29] and Wang and Huang [28]. This catalytic action was attributed to the role of Fe and may also be attributed to $\mathrm{Mn}$ at mineral surfaces (Shindo [29]). Ziechmann [30] found silicic acid to be a catalyst for the formation of humic polymers from hydroquinone, but it is still unclear whether this effect is due to impurities, e.g., of Fe or Mn.

Other reactions of soil humic substances may also include polycondensation reactions and electrostatic interactions, e.g., a basic amino acid reacting with negatively charged groups of the humic substances or the formation of hydrogen bonds, charge transfer complexes, or hydrophobic interactions between humic molecules.

Despite the differences in the details of the concepts of the polymerization and formation of soil humic substances between different research groups, the reported concepts agree so far in four central, experimental supported assumptions:

1. The dead organic matter in soil arising mainly from plants and soil microorganisms is partially degraded and split into small units.

2. The remaining molecules such as phenols, phenylpropene units, amino acids, peptides, amino sugars, and sugars react, polymerize, and polycondensate as described, partly catalyzed by soil oxidoreductases or mineral surfaces, and partly mediated by soil microorganisms to form medium to higher molecular weight organic substances, specifically humic substances. Humic molecules of different molecular masses form supramolecular bonds resulting in a humic network.

3. The humic substances show high resistance and stability against microbial degradation partly because of the biochemical stability of the molecules against microbial attack (Haider [31,32]), and partly by the reaction of humic substances with inorganic soil components during and after the formation of the humic substances. As a result, clay-humic substances complexes are formed or humic substances form complexes with di- or trivalent cations, such as $\mathrm{Ca}^{2+}, \mathrm{Cu}(\mathrm{II}), \mathrm{Fe}(\mathrm{III})$, or $\mathrm{Al}(\mathrm{III})$. Both sorption to mineral surfaces and complexation of cations have been shown to reduce the rate of degradation of organic molecules in soil [33-36].

4. The chemical results allow the formulation of structural models for humic substances. Stevenson ([6], chapter 12, pp. 285-302) gave an overview on various models of humic substances. Most of them show an aromatic core; however, the models vary in the degree of aromaticity, molecular weight, and intramolecular bonding (Schnitzer [1]; Schulten and Schnitzer [37]).

\section{Criticism of the Concept of Humic Substances}

The concept reported herein has been criticized or rejected by several papers with increasing intensity (Schmidt et al. [38]; Glaser et al. [39]; von Lützow et al. [40]; Kögl-Knabner et al. [41]; Kleber et al. [42], Lehmann and Kleber [43]). Lehmann and Kleber [43] proposed a "traditional view" (humic substances concept) and a "new and emergent view" on soil organic matter. Some of the misunderstandings are mentioned below.

As shown before, the central reaction in the formation of soil humic substances is the chemical or biochemical polymerization from phenol units mediated by soil oxidoreductases, soil mineral surfaces, and microorganisms, e.g., soil fungi and the aggregation of humic molecules.

Lehmann and Kleber [43] did not collect arguments against the humic polymerization theory; they even do not mention it. Instead, they postulate a view of "selective preservation" and "progressive decomposition." According to their view on soil organic matter, large molecules such as lignin, cellulose, and proteins are decomposed by microorganisms with more or less mean residence time in 
soil. Any reason why phenylpropene units or phenols from the decomposition of lignin should not polymerize and further react, e.g., with amino acids or amino sugars, is not given or mentioned [43]. Their paper is mainly based on the opposition of humic substances as the "traditional view" and their view as the "emergent view".

However, Lehmann and Kleber [43] proved through at least at two points that their knowledge on humic substances is limited.

They criticize with some justification the alkaline extraction step of humic substances with 0.1 or $0.5 \mathrm{M} \mathrm{NaOH}$, which may produce artifacts especially during extraction under an $\mathrm{O}_{2}$ atmosphere. However, they ignore the fact that mild extracting solutions are used, e.g., dimethylformamide or dimethylsulfoxide or complexing solutions at pH 7.0 or 8.5 (e.g., Ziechmann [4]; Stevenson [6]; Hayes [44]). In particular, the detailed discussion by Hayes [44] on the extraction of soil organic matter is ignored by Lehmann and Kleber [44]. The problem of artifacts forming during extraction may be minimized by using humic substances in the soil solution for further investigations.

More seriously, they argue "the harsh alkaline treatment at $\mathrm{pH} 13$ ionizes compounds that would never dissociate within the wider soil $\mathrm{pH}$ range $(\mathrm{pH} 3.5-8.5)$... " [43]. Or, as formulated by Kleber et al. [42]: "It is noteworthy that the materials extracted at $\mathrm{pH}$ 13, i.e., the humic acids listed under ... must be considered as resulting from a chemical fractionation process (compare the dissociation state of functional groups at $\mathrm{pH} 13$, Table $2 \mathrm{a}-\mathrm{c}$ ) that ionized all carboxyl groups to an extent of $100 \%$. Probably for this reason there is a greater proportion of carboxylic groups in the operationally defined Has (humic acids) than in most natural compounds."

The two papers-Lehmann and Kleber [43] and Kleber et al. [42] - the authors postulate that "ignorant" humic substances soil chemists determine the acidity of carboxylic groups at $\mathrm{pH} 13$. However, the $\mathrm{COOH}$ - acidity of humic substances is determined by the aid of titration methods over a wide $\mathrm{pH}$ range [1] or by the Ca-acetate procedure (e.g., Perdue [45]). The reason for the often relatively high content of $\mathrm{COOH}$ - groups is not an assumed determination at $\mathrm{pH} 13$. Obviously, Lehmann and Kleber and Kleber et al. do not know that the $\mathrm{pH}$ of the extracting solution is not the $\mathrm{pH}$ that is used to determine $\mathrm{COOH}$ - and $\mathrm{OH}$ - acidity. Furthermore, humic substances soil chemists are aware of the operational definition of $\mathrm{COOH}$ - groups arising from the methods used.

The ignorance towards humic substances in the paper of Lehmann and Kleber [43] as well as the lack of systematicity in the review of Kleber et al. [42] have origins in the lack of a realistic concept of soil organic matter transformation.

The consequences of ignoring the function of humic substances in soil, from the polymerization of phenolic units to the formation of a humic structure in soil, may represent a deficit in their consideration of fundamental processes in the soil/plant system.

Another aspect of critiques towards the concept of humic substances is presented, e.g., by Schmidt et al. [38] and Glaser et al. [39]. These two research groups attributed aromatic carbon within soil organic matter mainly to fire-induced organic carbon or black carbon (BC). With the aid of this interpretation, they dispensed themselves from the investigation of humic substances in soil. This opinion may imply that humic substances are simply nonexistent in soil, as similarly suggested by Lehmann and Kleber [43]. If this is indeed the case, what is the framework and experimental basis for $\mathrm{BC}$, which has been highlighted in soil organic matter research for more than two decades?

\section{Black Carbon in Soil}

Black carbon (BC) from fire-affected organic matter has received increasing attention in soil organic matter research since the basic publication of Goldberg [46]. However, the central question is to what extent does BC exist in soil? Masiello [47] reviewed BC as a byproduct of biomass burning with properties ranging from slightly charred biomass to char, coal, and finally to soot, which he defined as combustion continuum. All these fire-affected components exhibit a high carbon content, are heterogeneous, and are dominated by aromatic structures ranging from oxygenated aromatic ring structures to polycyclic aromatic hydrocarbon [48]. 
The determination of BC has been a long-standing matter of debate. Thermal oxidation, combinations of pre-extraction and thermal oxidation, oxidation, and the subsequent use of benzepolycarboxylic acids (BPCAS) and oxidation by UV irradiation are all important methods for the determination of BC $[49,50]$.

However, the evaluation of methods of determination of $B C$ in soil by different scientific groups shows that a strong experimental basis for the determination of $\mathrm{BC}$ does not yet exist.

Comparative results on the $\mathrm{BC}$ content of eight Australian soils determined by different methods were reported by Schmidt et al. [49].

Four of the six methods applied to determine $\mathrm{BC}$ used thermal oxidation to 340 or $370{ }^{\circ} \mathrm{C}$ without or with pre-extraction, with the loss after heating being attributed to BC. The fifth method used oxidation and the subsequent determination of benzene polycarboxylic acids (BPCAs) as markers of BC (after Glaser et al. [51]). Lastly, the sixth method used UV oxidation of soil organic matter, with the organic residue being determined by CP MAS ${ }^{13} \mathrm{C}$ NMR spectroscopy as BC (Skjemstad et al. [52,53]). The comparative results are remarkable [49].

Thermal oxidation without pre-extraction gave BC yields of between $4-6 \%(\mathrm{BC} /$ total soil organic matter) in the eight soils investigated, whereas the combination of pre-extraction with strong acids or in combination with $\mathrm{NaOH}$ decreased the measured $\mathrm{BC}$ values in the same soils to values between 0.05 and 3.95\% BC (Schmidt et al. [49]). This reduction can be explained by the fact that the pre-extraction of soil organic matter and especially humic substances will reduce artifacts in the BC determination during the heating process. Thus, an adequate pre-extraction step is required to improve the accuracy of BC determination by thermal oxidative methods. Simpson and Hatcher [54] showed that thermal oxidative methods can overestimate the $\mathrm{BC}$ content because of $\mathrm{BC}$ formation during the thermal oxidative treatment.

Using the BPCA marker method, Schmidt et al. [38] found BC values of between 3.7 and $13.1 \%$ BC in the same eight soils. These values were between a factor of 2-10 higher compared to those achieved by thermal oxidation methods, which itself may overestimate the $\mathrm{BC}$ content in soils. The possibility that humic substances were oxidized to BPCAs during the analytic procedure, which may have led to a BC overestimation, was not checked by Schmidt et al. [38]. The overestimation of BC by the BPCA marker method was shown by Brodowski et al. [55]. They found that the $\mathrm{HCl}$ pretreatment forms additional BPCAs, leading to a strong $\mathrm{BC}$ overestimation. This $\mathrm{HCl}$ pretreatment was used by Schmidt et al. [49] and by Glaser et al. [51].

The sixth method employed by Schmidt et al. [49] was the UV method. In this approach, soil organic matter is destroyed by UV irradiation of high intensity and the remaining organic $C$ is determined as BC by NMR spectroscopy. The UV method gave BC concentrations between 1.14 and $32.5 \%$ in the same eight soils. In six of the eight soils the BC values determined by the UV method were by far the highest values, exceeding the BC values determined by thermal oxidation by factors up to more than 500 [49]. Obviously, the UV pretreatment did not destroy all of the soil organic matter that was not BC. Humic substances are relatively resistant to UV irradiation [56-59]. Consequently, part of the humic substances survive the irradiation and are determined as BC.

In summary, Schmidt et al. [49] showed that the BPCA marker method and the UV irradiation method gave very high $\mathrm{BC}$ values, exceeding the more reliable thermal oxidation method with pre-extraction by factors of between 10 and more than 100 . However, the authors did not discuss these discrepancies in their paper.

Hammes et al. [50] also checked several methods of BC determination and evaluated the determination of BC as well as "potential interfering materials". They used, among other materials, lignite coal free of $\mathrm{BC}$ and bituminous coal with a BC content of up to $10 \%$. The BPCA marker method gave a yield of $23.4 \%$ BC for the BC-free coal, the UV method gave a value of $26.9 \% \mathrm{BC}$. For the bituminous coal, the UV method gave a BC yield of up to more than $90 \%$ [50] despite of its real BC content being between 0 and $10 \%$. 
Kappenberg et al. [60] recently showed that BC-free plant materials yield to some extent BC, as determined by the BPCA marker method.

The obvious failure of the BPCA marker method to determine BC in soils probably led to a strong overestimation of $\mathrm{BC}$ by Glaser et al. [51,61]. The conclusions concerning the fertility of Terra preta soils of the humid tropics drawn by Glaser et al. [39] should have been critically evaluated by the authors after the publication of the method-comparing study by Schmidt et al. [49] and the study of Borowski et al. [55].

The obvious failure of the UV method to determine accurate BC values in soil [49] did not hinder Schmidt et al. [61] from publishing results on the BC contents of European chernozems, in which they measured extremely high BC values of between 15 and 35\% related to soil organic matter. In addition, they did not stop Skjemstad et al. [62] from publishing data on the BC content of US soils between 10 and $35 \%$. In both cases the chosen method was the UV method.

Hammes et al. [50] intended to check the methods on BC determination in soils. They used melanoidin, which was stated "to have similar chemistry to that of natural organic matter" according to one single reference. They obviously avoided including humic substances as reference material. Remember that humic substances also contain fused aromatic rings $[1,37,63]$, which may be measured as BC, e.g., by the BPCA marker method. The possible interference of soil humic substances in the determination of $\mathrm{BC}$ was not evaluated by Hammes et al. [50]. With the aid of model polymers from hydroquinone, catechol, or pyrogallol as reference material, the effect of humic substances on the determination of BC would have been apparent even without using "natural" humic substances as a reference.

At present, the high BC values found via the BPCA marker method or the UV method as reported by Schmidt et al. [38], Glaser et al. [64], Schmidt et al. [61], and Skjemstad et al. [62] are not reliable. Rather, they probably represent a strong overestimation of $\mathrm{BC}$ and the conclusions drawn from these values should be urgently reevaluated.

However, the picture is even more complicated. In soil, BC molecules and humic molecules may interact by several mechanisms, as illustrated in Figure 4.

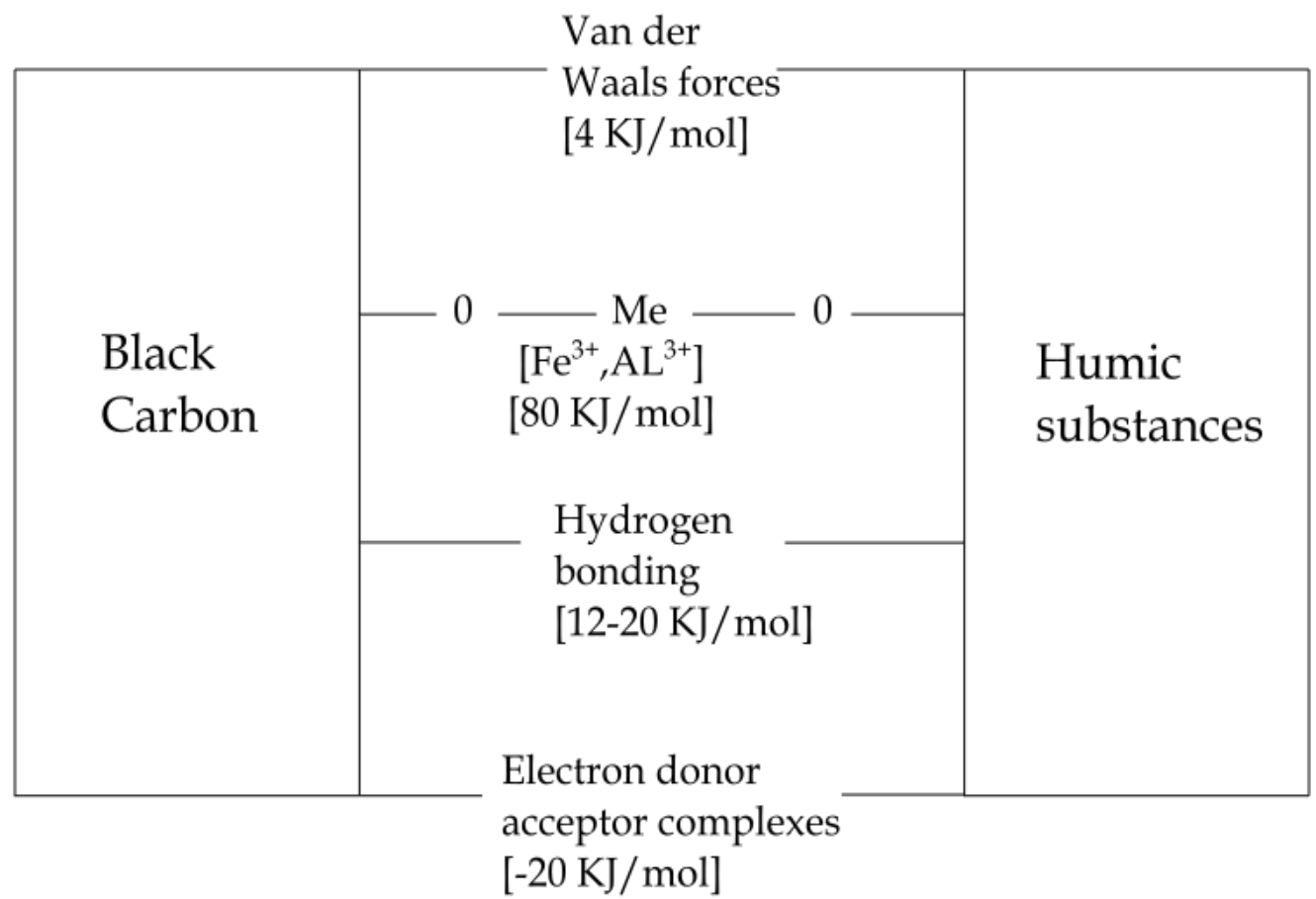

Figure 4. Principal chemical interactions between black carbon molecules and humic substances. In square brackets are approximate bonding energies. 
For the reaction products between humic substances and BC molecules, several interactions are illustrated in Figure 4. The question is to what extent will humic substances and $B C$ be measured as solely BC, as determined by different methods?

\section{Humic Substances in Soils: A Reformulated View}

Undoubtedly, a variety of polyphenols and benzene carboxylic acids are produced in soil from the degradation of lignin and microbial synthesis.

With the aid of catalysts such as Fe(III)-Fe(II), Mn(IV)-Mn(III)-Mn(II), or soil oxidoreductases such as polyphenoloxidases, brown to dark brown polymers are synthesized, also incorporating amino acids, amino sugars, sugars [6], probably black carbon, and a variety of organic xenobiotics, e.g., triazines (Senesi et al. [65]; Müller-Wegener [66,67]), or surfactants [58,68].

Recent studies have developed concepts of molecular and supramolecular structures of humic substances (Wershaw [69]; Piccolo [70,71]; Sutton and Sposito [72]). Inter- or supramolecular forces between humic molecules have been already reported, e.g., by Schnitzer [1], Flaig et al. [3], and Schulten and Schnitzer [37]. The novelty of the more recent papers is that molecular masses of humic substances are determined to be much lower than those reported earlier.

Von Wandruszka [73] and Wershaw [69] described a surfactant-like aggregation of humic molecules by forming micelles with interior hydrophobic regions and exterior hydrophilic regions of amphiphilic humic molecules. As a result of size exclusion chromatography, Piccolo and coworkers (Piccolo $[70,71]$ ) suggested the formation of supramolecular associations of relatively small humic molecules linked together by hydrophobic interactions and hydrogen bonds. Reviewing this "new view" of supramolecular structures, Sutton and Sposito [72] reported molecular masses between 500 and 6.000 Da. However, Piccolo et al. [24] and Cozzolino and Piccolo [25] turned loosely bound humic suprastructures into true polymers by treatment with peroxidase. The results of Piccolo and coworkers do not necessarily contradict other results on higher molecular weight humic structures. If the activity of catalysts for the polymerization reactions of humic substances is low, then supramolecular structures with humic units of relatively low molecular masses may successfully compete with further polymerization reactions.

Additionally, bridging humic molecules by polyvalent cations may be an important mechanism to aggregate humic molecules and increase their apparent molecule masses, as shown for $\mathrm{Mg}^{2+}$ by Engebretson and von Wandruszka [74]. Nuzzo et al. [75] demonstrated the effect of iron(III) on the conformation of humic substances. The structures are destroyed if the humic substances are extracted with strong alkaline solutions and subsequently precipitated by a strong acid such as $\mathrm{HCl}$ to remove inorganic "impurities". Extractants such as dimethyl formamide or dimethylsulfoxide may be an alternative with respect to a less destructive extraction procedure (Hayes [44]).

The effect of hydrophilic complexing agents such as citric acid or phytate on the solubility of humic substances in soil may be due to the complexation of bridging cations such as $\mathrm{Al}(\mathrm{III})$ or $\mathrm{Fe}(\mathrm{III})$ [26,76].

Considering the variety of chemical, biochemical, and biological mechanisms of formation of humic substances, the high plasticity of the humic system can be explained.

Humic substances can adsorb organic and inorganic molecules and form stable complexes, e.g., with metals such as $\mathrm{Fe}(\mathrm{III}), \mathrm{Al}(\mathrm{III})$, or $\mathrm{Cu}(\mathrm{II})$.

A main feature is the possibility of incorporating inorganic or organic molecules into the humic network. That means that reactions with non-humic substances may occur within interior parts of the humic structure and will have a strong effect on the possible remobilization, e.g., of xenobiotica. This is supposed to be the main origin of bound residues in soil.

Thus, the concept of humic substances includes physicochemical reactions, biochemical reactions, and biological processes, and therefore presents a strong advantage over concepts described by Lehmann and Kleber [43], such as "selective preservation" and "progressive decomposition" models which emphasize biological reactions. 
The relevance of the physicochemical-biochemical model of the formation of humic substances and their transformation (humification) may be illustrated by some examples.

\subsection{Reactions of Humic Substances with Organic Xenobiotics}

\subsubsection{Reaction with Triazines}

Senesi et al. [65] and Müller-Wegener [66,67,77] investigated the reaction between triazines and humic substances in detail and found ion-ion interactions and electron donor-acceptor complexes as main bonding mechanisms, which led to a strong incorporation of triazine molecules into the humic framework. The content of phenolic $\mathrm{OH}$ - groups of humic substances is of high relevance for the strong binding of atrazine molecules [67].

\subsubsection{Interaction of Humic Substances and Surfactants}

Surfactants play an important role as organic pollutants. Gerke and Ziechmann [78] investigated the reaction between a cationic and an anionic surfactant, dodecyl pyridinium chloride (DPC) respective linear Na-dodecyl benene sulfonate (LAS), and found a strong interaction between the cationic surfactant and humic substances and a weak, hydrophobic interaction between humic substances and the anionic surfactant.

The photodegradation of the cationic surfactant was strongly increased in the presence of humic substances, whereas in the presence of humic substances the photodegradation of the anionic LAS was reduced $[58,79]$.

The photooxidation of humic substances allowed the release of several radicals, $\mathrm{OH}, \mathrm{R}-\mathrm{COO}$, and $\mathrm{O}_{2}[57,58]$, which induced an increased photodegradation of the bound DPC molecules compared to a system without photooxidation. Thus, without knowledge of the physicochemical properties of soil humic substances, the photodegradation of surfactants in soil cannot be described.

\subsection{Reactions of Humic Substances with Inorganic Ions in Soil}

\subsubsection{Reactions with Micronutrient Metals}

The plant availability of micronutrients in soil, especially $\mathrm{Fe}$ and $\mathrm{Cu}$, cannot be explained without consideration of the interaction of these metals with soil humic substances.

The solubility of $\mathrm{Fe}^{3+}$ and its monomeric hydroxy species strongly depends on the association with stable soil organic matter, humic substances. In soil, the Fe transport to the plant roots strongly depends on the soil solution concentrations which are often controlled by organic Fe(III) complexes with low molecular weight organic anions or with dissolved humic substances (Gerke [80,81]). Marschner and Römheld [82] described a strategy of higher plants to acquire Fe from soil which they called strategy I. This strategy, which is employed bydicotyledeneous plants, includes the transport of $\mathrm{Fe}(\mathrm{III})$ in the soil solution to the plant root as an organic complex, either with low molecular weight organic acids or as a humic-Fe(III) complex; the reduction of $\mathrm{Fe}(\mathrm{III})$ at the root surface by plasmalemma membrane-bound oxidoreductase; the liberation of Fe(II) from the organic complexes due to the much lower complexation stability of organic Fe(II) complexes; and the uptake of Fe as free Fe(II). Cesco et al. [83] showed that cucumber, as a strategy I plant species, makes great use of Fe in Fe-humate complexes. Varanini and Pinton [84] reviewed the high potential of humic substances to improve the Fe nutrition of higher plants even at high $\mathrm{pH}$, where the Fe solubility in soil often is low.

Humic substances strongly affect the availability of $\mathrm{Cu}$ in soil. Most of the $\mathrm{Cu}$ in the soil solution is organically bound (Gerke [80], pp. 194-203), which means that most of the Cu transported in soil to the roots is organically complexed. However, in soils high in humified organic matter, e.g., peaty soils, $\mathrm{Cu}$ often is firmly bound to the non-dissolved organic matter which sometimes induces $\mathrm{Cu}$ deficiency in higher plants, also highlighting the importance of humic substances on $\mathrm{Cu}$ availability.

For the interactions of humic substances and metals, see also Senesi et al. [85]. 


\subsubsection{Humic $\mathrm{Al}(\mathrm{Fe})-\mathrm{Phosphate}$ Complexes in Soil}

Humic substances form complexes with orthophosphate (P), via $\mathrm{Fe}(\mathrm{III})$ or $\mathrm{Al}(\mathrm{III})$ bridges, which are of great importance in various soils (Levesque and Schnitzer [86]; Gerke [35]). Often the role of soil humic substances on soil $\mathrm{P}$ availability is assumed to be due to competitive adsorption binding to the same adsorption sites in soil (Borggard et al. [87]; Fu et al. [88]). However, Gerke [36] showed that $\mathrm{P}$ in humic-Fe(Al)-P complexes can be easily mobilized by organic acid anions or upon acidification, which may be the clue for the relatively high availability of humic-associated $\mathrm{P}$ in soil.

A Spanish group of soil scientists, plant nutritionists, and production managers are working on the use of humic substances in fertilizer production [63,89], emphasizing the effect of humic substances on $\mathrm{P}$ and micronutrient availability.

Also, in lakes, humic-associated phosphate may control P speciation in solution and P availability to algae (De Haan et al. [90] and Jones et al. [91]).

\subsection{Effects of Humic Substances on Plant Growth in Higher Plants}

Besides the effects of humic substances on the acquisition of mineral nutrients, there has been a long-lasting debate on the direct effect of humic substances on plant growth. Flaig [92] summarized some of the older results on this topic. He discussed the role of chinoid molecules on plant growth and the phytohormone-like activity of some humic fractions. More recently, Nardi et al. [93] and Trevisan et al. [94] summarized some of the effects of humic substances and their fractions on higher plants. Nardi et al. [93] differentiated between fractions of humic substances of lower molecular size $(<3.500 \mathrm{Da})$ and those of higher molecular size ( $>3.500 \mathrm{Da})$. Molecules of the lower size fraction can reach the root plasmalemma membrane and may be taken up, whereas the higher molecular mass fraction may interact with the cell wall. Nardi et al. [93] stated that respiration and photosynthesis may be affected by humic substances and that humic matter may have hormone-like activity. Trevisan et al. [94] described that humic substances may contain auxines or may have auxin-like activity, also supporting the hormone-like effect of humic substances on higher plants. Canellas et al. [95] summarized their results of fulvic and humic acids as bio-stimulants. The initial stimulation by humic substances is the induction of the plasmalemma membrane $\mathrm{H}^{+}$-ATPase, which has an effect on root growth promotion, activation of nutrient uptake, activation of $\mathrm{Ca}^{2+}$, and anion channels affecting carboxylate exudation. Parallel physiological pathways within the plants may be affected [95]. This work combines the effect of humic substances on nutrient uptake and on physiological pathways which strongly affect the growth of horticultural plants [95].

\section{Concluding Remarks}

Humic substances in soils are synthesis products of phenolic substances which form radicals (molecules with a free, unpaired electron) which polymerize. They have a unique ability to incorporate a variety of organic and inorganic molecules and elements, including amino acids, peptides, sugars, lignin fragments, and a wide variety of xenobiotics, such as pesticides and surfactants.

Because of this pathway of synthesis, humic substances in soil possess an aromatic core, which accounts often for $30-60 \%$.

Humic substances have important physical and chemical functions in soil, among them a high water-holding capacity, a high cation exchange capacity, and the abilities to adsorb or complex cationic nutrients such as $\mathrm{K}^{+}, \mathrm{Ca}^{2+}, \mathrm{Fe}(\mathrm{III})$, and $\mathrm{Cu}(\mathrm{II})$, to immobilize heavy metals such as $\mathrm{Pb}$ or $\mathrm{Cd}$, and to strongly affect the availability of $\mathrm{P}$ in soil.

Humic substances also incorporate and immobilize xenobiotics, e.g., pesticides, PAH, or surfactants, which may lead to "bound residues" in soil.

Humic substances or some of their fractions can improve the growth of higher plants in soil, probably by various mechanisms. 
The aromaticity of humic substances in soil has previously been questioned, which is probably mainly due to misinterpretations of $\mathrm{CP} M A S^{13} \mathrm{C}$ NMR spectroscopy. Moreover, the aromaticity of soil organic matter is sometimes assumed to be a result of the accumulation of black carbon in soil. However, the determination of black carbon by the commonly used BPCA marker method or by the UV oxidation method is known to strongly overestimate black carbon in soil.

Lehmann and Kleber [43] stated that no humic substances exist in soil. They gave no argument for this statement, but simply criticized the method of extraction of humic substances with $\mathrm{NaOH}$, which may yield artifacts.

Critiques of the concept of humic substances require a substantial experimental background and sophisticated concepts on the chemistry of organic matter in soil. Such critiques should be used to improve experimental approaches and theoretical framework in humic substances research.

Acknowledgments: I thank Thomas K.H. Gerke for technical support!

Conflicts of Interest: The author declares no conflict of interest.

\section{References}

1. Schnitzer, M. Humic substances: Chemistry and reactions. In Soil Organic Matter; Schnitzer, M., Kahn, S.U., Eds.; Elsevier: New York, NY, USA, 1978; pp. 1-64.

2. Schnitzer, M. A lifetime perspective on the chemistry of soil organic matter. Adv. Agron. 2000, 68, 1-58.

3. Flaig, W.; Beutelspacher, H.; Rietz, E. Chemical composition and physical properties of humic substances. In Soil Components; Gieseking, J.E., Ed.; Springer: Berlin/Heidelberg, Germany; New York, NY, USA, 1975; Volume 1, pp. 1-211.

4. Ziechmann, W. Huminstoffe; Verlag Chemie: Weinheim, Germany, 1980.

5. Aiken, G.R.; Mc Knight, D.M.; Wershaw, R.; MacCarthy, P. Humic Substances in Soil, Sediment and Water; John Wiley: New York, NY, USA, 1985.

6. Stevenson, F.J. Humus Chemistry. Genesis, Composition, Reactions; John Wiley: New York, NY, USA, 1994.

7. Hatcher, P.G.; Breger, J.A.; Dennis, L.W.; Maciel, G.E. Solid-state ${ }^{13}$ C NMR of sedimentary humic substances: New revelations on their chemical composition. In Aquatic and Terrestrial Humic Materials; Christman, R.F., Gjessing, E.T., Eds.; Ann Arbor Science: Ann Arbor, MI, USA, 1983; pp. 37-82.

8. Hasselmann, N. Untersuchungenzum Einbau von Kohlenhydraten in die Huminstoff-Matrix. Ph.D. Thesis, Georg-August Universität, Göttingen, Germany, 1987.

9. Smernik, R.J.; Oades, J.M. The use of spin counting for determining quantitation in solid state ${ }^{13} \mathrm{C}$ NMR spectra of natural organic matter. 1. Model systems and the effect of paramagnetic impurities. Geoderma 2000, 96, 101-129. [CrossRef]

10. Mao, J.-D.; Hu, W.-G.; Schmidt-Rohr, K.; Davies, G.; Ghabbour, E.A.; Xing, B. Quantitative characterization of humic substances by solid-state Carbon-13 nuclear magnetic resonance. Soil Sci. Soc. Am. J. 2000, 64, 873-884. [CrossRef]

11. Keeler, C.; Maciel, G.E. Quantitation in the solid-state ${ }^{13} \mathrm{C}$ NMR analysis of soil and organic soil fractions. Anal. Chem. 2003, 75, 2421-2432. [CrossRef] [PubMed]

12. Mao, J.-D.; Schmidt-Rohr, K. Accurate quantification of aromaticity and nonprotonated aromatic carbon fraction in natural organic matter by ${ }^{13} \mathrm{C}$ solid-state nuclear magnetic resonance. Environ. Sci. Technol. 2004, 38, 2680-2684. [CrossRef] [PubMed]

13. Kögl-Knabner, I.; Zech, W.; Hatcher, P.G.; de Leeuw, J.W. Fate of plant components during biodegradation and humification. In Forest Soils: Evidence from Structural Characterization of Individual Biomolecules; Wilson, W.S., Ed.; Royal Society of Chemistry: Cambridge, UK, 1991; pp. 61-70.

14. Urbanski, L.; Kölbl, A.; Lehndorff, E.; Houtermans, M.; Schad, P.; Zhang, G.-L.; Utami, S.R.; Kögl-Knabner, I. Paddy management on different soil types does not promote lignin accumulation. J. Plant Nutr. Soil Sci. 2017, 180, 366-380. [CrossRef]

15. Peerson, O.B.; Wu, X.; Kustanovick, I.; Smith, S.O. Variable-amplitude cross-polarization MAS NMR. J. Magn. Res. 1993, 104, 334-339. [CrossRef]

16. Cook, R.L.; Langford, C.H.; Yamdagni, R.; Preston, C.M. A modified cross-polarization magic angle spinning ${ }^{13} \mathrm{C}$ NMR procedure for the study of humic materials. Anal. Chem. 1996, 68, 3979-3986. [CrossRef] 
17. Mao, J.; Cao, X.; Olk, D.L.; Chu, W.; Schmidt-Rohr, K. Advanced solid-state NMR spectroscopy of natural organic matter. Prog. Nucl. Magn. Reson. Spectrosc. 2017, 100, 17-51. [CrossRef] [PubMed]

18. Schöning, I.; Knicker, H.; Kögl-Knabner, I. Intimate association between $\mathrm{O} / \mathrm{N}$-alkyl carbon and iron oxides in clay fractions of forest soils. Org. Geochem. 2005, 36, 1378-1390. [CrossRef]

19. Spielvogel, S.; Prietzel, J.; Kögl-Knabner, I. Soil organic matter stabilization in acidic forest soils is preferential and soil type specific. Eur. J. Soil Sci. 2008, 674-692. [CrossRef]

20. Haider, K.; Martin, J.P. Synthesis and transformation of phenolic compounds by Epicoccum nigrum in relation to humic acid formation. Proc. Soil Sci. Soc. Am. 1967, 31, 766-772. [CrossRef]

21. Weichelt, T. Chemical alteration of natural lignin by interactions with humic like autoxidation products of pyrogallol (1,2,3-trihydroxybenzene). In Soil Organic Matter Studies; IAEA, FAO, Eds.; IAEA: Wien, Austria, 1977; Volume II, pp. 67-82.

22. Haider, K.; Nagar, B.R.; Saiz, C.; Meuzelaar, H.L.C.; Martin, J.P. Studies on soil humic compounds, fungal melanins, and model polymers by pyrolysis. In Soil Organic Matter Studies; IAEA, FAO, Eds.; IAEA: Wien, Austria, 1977; Volume II, pp. 213-220.

23. Martin, J.P.; Haider, K.; Bondietti, E. Properties of model humic acids synthesized by phenoloxidase and autoxidation of phenols and other components formed by soil fungi. In Proceedings Intern Meeting Humic Substances; Pudoc: Wageningen, The Netherlands, 1975; pp. 171-186.

24. Piccolo, A.; Cozzolino, A.; Conte, P.; Spaccini, R. Polymerization of humic substances by an enzyme catalyzed oxidative coupling. Naturwissenschaften 2000, 87, 391-394. [CrossRef] [PubMed]

25. Cozzolini, A.; Piccolo, A. Polymerization of dissolved humic substances catalyzed by peroxidase. Effects of pH and humic composition. Org. Geochem. 2002, 33, 281-294. [CrossRef]

26. Wang, T.S.C.; Li, S.W.; Huang, P.M. Catalytic polymerization of phenolic compounds by a latosol. Soil Sci. 1978, 126, 81-86. [CrossRef]

27. Wang, T.S.C.; Wang, M.C.; Yue, L.; Huang, P.M. Catalytic synthesis of humic substances by natural clays, silts and soils. Soil Sci. 1983, 135, 350-360. [CrossRef]

28. Wang, M.C.; Huang, P.M. Catalytic polymerization of hydroquinone by nontronite. Can. J. Soil Sci. 1987, 67, 867-875. [CrossRef]

29. Shino, H. Catalytic synthesis of humic acids from phenolic compounds by Mn(IV) oxide (Birnessite). Soil Sci. Plant Nutr. 1990, 36, 679-682. [CrossRef]

30. Ziechmann, W. Über modellreaktionenzur bildungsynthetischer huminsäuren. 2. Die synthese von huminsäuren im neutralen millieu. Brennstoff-Chemie 1960, 41, 334-340.

31. Haider, K. Biochemie der umsetzung von pflanzenrückständenzu huminstoffen. In Refraktäre Organische Säuren in Gewässern; Frimmel, F.H., Abbt-Braun, G., Eds.; Verlag Chemie: Bonn, Germany, 1993; pp. $215-232$.

32. Haider, K. Problems related to the humification processes in soils of temperate climates. In Soil Biochemistry; Bollag, J.M., Stotzky, G., Eds.; Marcel Dekker: New York, NY, USA, 1992; Volume 7, pp. 55-94.

33. Boudot, J.P. Relative efficiency of complexed aluminum, noncrystalline Al hydroxide, allophone and imogolite in retarding the biodegradation of citric acid. Geoderma 1992, 52, 29-39. [CrossRef]

34. Jones, D.L.; Edwards, A.C. Influence of sorption on the biological utilization of two simple carbon substrates. Soil Biol. Biochem. 1998, 30, 1895-1902. [CrossRef]

35. Gerke, J. Humic (organic matter)-Al(Fe)-phosphate complexes: An underestimated phosphate form in soils and source of plant-available phosphate. Soil Sci. 2010, 175, 417-425. [CrossRef]

36. Gerke, J. The acquisition of phosphate by higher plants: Effect of carboxylate release by the roots. A critical review. J. Plant Nutr. Soil Sci. 2015, 178, 351-364. [CrossRef]

37. Schulten, H.R.; Schnitzer, M. A state of the art structural concept for humic substances. Naturwissenschaften 1993, 80, 29-30. [CrossRef]

38. Schmidt, M.W.; Skjemstad, J.O.; Gehrt, E.; Kögl-Knabner, I. Charred organic carbon in German chernozemic soils. Eur. J. Soil Sci. 1999, 50, 351-365. [CrossRef]

39. Glaser, B.; Haumeier, L.; Guggenberger, G.; Zech, W. The Terra preta phenomenon: A model for sustainable agriculture in the humid tropics. Naturwissenschaften 2001, 88, 37-41. [CrossRef] [PubMed]

40. Von Lützow, M.; Kögl-Knabner, I.; Ekschmidt, R.; Matzner, E.; Guggenberger, G.; Marschner, B.; Flessa, H. Stabilization of organic matter in temperate soils: Mechanisms and their relevance under different soil conditions: A review. Eur. J Soil Sci. 2006, 57, 426-445. [CrossRef] 
41. Kögl-Knabner, I.; Guggenberger, G.; Kleber, M.; Kandeler, E.; Kalbitz, K.; Scheu, S.; Eusterhues, K.; Leinweber, P. Organo-mineral associations in temperate soils: Integrating biology, mineralogy, and organic matter chemistry. J. Plant Nutr. Soil Sci. 2008, 171, 61-82. [CrossRef]

42. Kleber, M.; Eusterhues, K.; Keiluweit, M.; Mikutta, C.; Mikutta, R.; Nico, P.S. Mineral-organic associations: Formation, properties, and relevance in soil environments. Adv. Agron. 2015, 130, 1-140.

43. Lehmann, J.; Kleber, M. The contentious nature of soil organic matter. Nature 2015, 528, 61-68. [CrossRef] [PubMed]

44. Hayes, M.H.B. Solvent systems for the isolation of organic components from soils. Soil Sci. Soc. Am. J. 2006, 70, 986-994. [CrossRef]

45. Perdue, E.M. Acidic functional groups of humic substances. In Humic Substances in Soil, Sediment and Water; Aiken, G.R., McKnight, D., Wershaw, R., MacCarthy, P., Eds.; John Wiley: New York, NY, USA, 1985; pp. 493-526.

46. Goldberg, E.D. Black Carbon in the Environment; John Wiley: New York, NY, USA, 1985.

47. Masiello, C.A. New directions in black carbon organic geochemistry. Mar. Chem. 2004, 92, 201-213. [CrossRef]

48. Baldock, J.A.; Smernik, R.J. Chemical composition and bioavailability of thermal altered Pinusresinosa (Red pine) wood. Org. Geochem. 2002, 34, 1093-1109. [CrossRef]

49. Schmidt, M.W.; Skjemstad, J.-O.; Czimczik, C.I.; Glaser, B.; Prentice, K.M.; Gelinas, Y.; Kuhlbusch, T.A. Comparative analysis of black carbon in soils. Glob. Biochem. Cycles 2001, 15, 163-167. [CrossRef]

50. Hammes, K.; Schmidt, M.W.I.; Smernik, R.J.; Currie, L.A.; Ball, W.P.; Nguyen, T.H.; Louchouran, P.; Houel, S.; Gustafsson, O.; Elmquist, M.; et al. Comparison of quantification methods to measure fire-derived (black/elemental) carbon in soils and sediments using reference materials from soil, water, sediment and the atmosphere. Glob. Biochem. Cycles 2007, 21, 1-18. [CrossRef]

51. Glaser, B.; Haumeier, L.; Guggenberger, G.; Zech, W. Black carbon in soils: The use of benzenecarboxylic acids as specific markers. Org. Geochem. 1998, 29, 811-819. [CrossRef]

52. Skjemstad, J.O.; Clarke, J.A.; Taylor, J.A.; Oades, J.M.; McClure, S.G. The chemistry and nature of protected carbon in soil. Aust. J. Soil Res. 1996, 34, 251-271. [CrossRef]

53. Skjemstad, J.O.; Taylor, J.A.; Smernik, R.J. Estimation of charcoal (char) in soils. Commun. Soil Sci. Plant Anal. 1999, 30, 2283-2298. [CrossRef]

54. Simpson, M.J.; Hatcher, P.G. Overestimates of black carbon in soils and sediments. Naturwissenschaften 2004, 91, 436-440. [CrossRef] [PubMed]

55. Brodowski, S.; Rodionow, A.; Haumeier, L.; Glaser, B.; Amelung, W. Revised black carbon assessment using benzene polycarboxylic acids. Org. Geochem. 2005, 36, 1299-1310. [CrossRef]

56. Francko, D.A.; Heath, R.T. Functionally distinct classes of complex phosphorus compounds in lake waters. Limnol. Oceanogr. 1979, 24, 463-473. [CrossRef]

57. Zika, R.G.; Cooper, W.J. Photochemistry of Environmental Aquatic Systems; American Chemical Society (ACS): Washington, DC, USA, 1987; Volume 327.

58. Hermann, R.; Gerke, J.; Ziechmann, W. Photodegradation of the surfactants Na-dodecylbenzenesulfate and dodecylpyridinium-chloride as affected by humic substances. Water Air Soil Pollut. 1997, 98, 43-55. [CrossRef]

59. Hens, M. Aqueous Phase Speciation of Phosphorus in Sandy Soils. Ph.D. Thesis, University of Leuven, Leuven, Belgium, 1999.

60. Kappenberg, A.; Bläsing, M.; Lehndorff, E.; Amelung, W. Black carbon assessment using benzene polycarboxylic acids: Limitations for organic-rich matrices. Org. Geochem. 2016, 94, 47-51. [CrossRef]

61. Schmidt, M.W.; Skjemstad, J.O.; Jäger, C. Carbon isotope geochemistry and nanomorphology of soil black carbon: Black chernozemic soils in central Europe originate from ancient biomass burning. Glob. Biogeochem. Cycles 2002, 16, 1123-1131. [CrossRef]

62. Skjemstad, J.O.; Reicosky, D.C.; Wilts, A.R.; Mcgowan, J.A. Charcoal carbon in U.S. agricultural soils. Soil Sci. Soc. Am. J. 2002, 66, 1249-1255. [CrossRef]

63. Erro, J.; Urrutia, O.; Baigorri, R.; Fuentes, M.; Zamerreno, G.; Garcia-Mina, J.M. Incorporation of humic-derived active molecules into compound NPK granulated fertilizers: Main technical difficulties and potential solutions. Chem. Biol. Technol. Agric. 2016, 3, 18-33. [CrossRef]

64. Glaser, B.; Balashov, E.; Haumeier, L.; Guggenberger, G.; Zech, W. Black carbon in density fractions of anthropogenic soils of the Brazilian amazon region. Org. Geochem. 2000, 31, 669-678. [CrossRef] 
65. Senesi, N.; Testini, C.; Miano, T.M. Interaction mechanisms between humic acids of different origin and nature and electron donor herbicides: A comparative IR and ESR study. Org. Geochem. 1987, 11, 25-30. [CrossRef]

66. Müller-Wegener, U. Einfluss von huminstoffen auf den eintrag von pflanzenschutzmitteln in das grundwasser. In Refraktäre Organische Säuren in Gewässern; Frimmel, F.H., Abbt-Braun, G., Eds.; Verlag-Chemie: Weinheim, Germany, 1993; pp. 79-87.

67. Müller-Wegener, U. Electron donor acceptor complexes between organic nitrogen heterocycles and humic acid. Sci. Total Environ. 1987, 62, 297-304. [CrossRef]

68. Gerke, J. Untersuchungenzur Bindung des Kationischen Tensids Laurylpyridiniumchlorid und des Anionischen Tensids Dodecylbenzolsulfonat an Huminstoffe-ein Modell der Reaktion in Böden und Gewässern. Ph.D. Thesis, Georg-August Universität, Göttingen, Germany, 1988.

69. Wershaw, R.L. Molecular aggregation of humic substances. Soil Sci. 1999, 164, 803-813. [CrossRef]

70. Piccolo, A. The supramolecular structure of humic substances. Soil Sci. 2001, 166, 810-832. [CrossRef]

71. Piccolo, A. The supramolecular structure of humic substances: A novel understanding of humus chemistry and implications in soil sciences. Adv. Agron. 2002, 75, 57-134.

72. Sutton, R.; Sposito, G. Molecular structure in humic substances: The new view. Environ. Sci. Technol. 2005, 39, 9009-9015. [CrossRef] [PubMed]

73. Von Wandruszka, R. The micellar model of humic acid: Evidences from pyrene fluorescence measurements. Soil Sci. 1998, 163, 921-930. [CrossRef]

74. Engebretson, R.R.; von Wandruszka, R. Kinetic aspects of cation enhanced aggregation in aqueous humic acids. Environ. Sci. Technol. 1998, 32, 488-493. [CrossRef]

75. Nuzzo, A.; Sanchez, A.; Fontaine, B.; Piccolo, A. Conformational changes of dissolved humic and fulvic superstructures with progressive iron complexation. J. Geochem. Explor. 2013, 129, 1-5. [CrossRef]

76. Helal, H.-M.; Dressler, A. Mobilization and turnover of soil phosphorus in the rhizosphere. J. Plant Nutr. Soil Sci. 1989, 152, 175-180. [CrossRef]

77. Müller-Wegener, U. Neuere Erkenntnissezur Wechselwirkung Zwischen s-Triazinen und Organischen Stoffen. Ph.D. Thesis, Georg-August Universität, Göttingen, Germany, 1984.

78. Gerke, J.; Ziechmann, W. Adsorption des kationischen tensids laurylpyridiniumchloridan huminstoffe, böden und komposte. Chem. Erde 1990, 51, 247-253.

79. Hermann, R. Modifiziertes Reaktionsverhalten von Huminstoffen Infolge Photochemisch Induzierter Prozesse Gegenüber Ausgewählten Organischen Substanzen und Anorganischen Ionen. Ph.D. Thesis, Georg-August Universität, Göttingen, Germany, 1993.

80. Gerke, J. Chemische Prozesse der Nährstoffmobilisierung in der Rhizosphäre und ihre Bedeutungfür den Übergangvom Boden in die Pflanze. Ph.D. Thesis, Georg-August Universität, Göttingen, Germany, 1995.

81. Gerke, J. Aluminum and iron(III) species in the soil solution including organic complexes with citrate and humic substances. J. Plant Nutr. Soil Sci. 1997, 160, 427-432. [CrossRef]

82. Marschner, H.; Römheld, V. Strategies of plants for acquisition of iron. Plant Soil 1994, 165, 261-274. [CrossRef]

83. Cesco, S.; Nikolic, M.; Römheld, V.; Varanini, Z.; Pinton, R. Uptake of ${ }^{59}$ Fe from soluble ${ }^{59}$ Fe-humate by cucumber and barley plants. Plant Soil 2002, 241, 121-128. [CrossRef]

84. Varanini, Z.; Pinton, R. Plant-soil relationship: Role of humic substances in iron nutrition. In Iron Nutrition in Plants and Rhizospheric Microorganisms; Barton, L.L., Abadia, J., Eds.; Springer: Heidelberg, Germany, 2006; pp. 153-168.

85. Senesi, N.; Miano, T.M.; Provenzano, M.R.; Brunetti, G. Spectroscopic characterization of metal-humic acid like complexes of earthworm-composted organic wastes. Sci. Total Environ. 1992, 117-118, 111-120. [CrossRef]

86. Levesque, M.; Schnitzer, M. Organic metallic interactions in soil: 6. Preparation and properties of fulvic acid-metal phosphates. Soil Sci. 1967, 103, 183-190. [CrossRef]

87. Borggaard, O.K.; Raben-Lange, B.; Gimsing, A.L.; Strobel, B.W. Influence of humic substances on phosphate adsorption by aluminum and iron oxides. Geoderma 2005, 127, 270-279. [CrossRef]

88. Fu, Z.; Wu, F.; Song, K.; Lin, Y.; Bai, Y.; Zhu, Y.; Giesy, J.P. Competitive interaction between soil-derived humic acid and phosphate. Appl. Geochem. 2013, 36, 125-131. [CrossRef] 
89. Urrutria, O.; Erro, J.; Guardado, I.; San Francisco, S.; Mandado, M.; Baigorri, R.; Yvin, J.C.; Garcia-Mina, J.M. Physico-chemical characterization of humic-metal-phosphate complexes and their potential application to the manufacture of new types of phosphate-based fertilizers. J. Plant Nutr. Soil Sci. 2014, 177, 128-136. [CrossRef]

90. De Haan, H.; Jones, R.I.; Salonen, K. Abiotic transformations of iron and phosphate in humic lake water revealed by double-isotopic labeling and gel filtration. Limnol. Oceanogr. 1990, 35, 491-497. [CrossRef]

91. Jones, R.I.; Salonen, K.; De Haan, H. Effect of dissolved humic substances on the speciation of iron and phosphate at different pH and ionic strength. Environ. Sci. Technol. 1993, 27, 1052-1059. [CrossRef]

92. Flaig, W. Mögliche beeinflussung von stoffwechsel und ertrag der pflanzendurch huminstoffe. In Refraktäre Organische Säuren in Gewässern; Frimmel, F.H., Abbt-Braun, G., Eds.; Verlag Chemie: Bonn, Germany, 1993; pp. 233-252.

93. Nardi, S.; Pizzeghello, D.; Muscolo, A.; Vianello, A. Physiological effects of humic substances on higher plants. Soil Biol. Biochem. 2002, 34, 1527-1536. [CrossRef]

94. Trevisan, S.; Francioso, O.; Quaggiotti, S.; Nardi, S. Humic substances biological activity at the plant-soil interface. Plant Signal. Behav. 2010, 5, 635-643. [CrossRef] [PubMed]

95. Canellas, L.P.; Olivares, F.L.; Aguiar, N.O.; Jones, D.; Nebioso, A.; Mazzei, P.; Piccolo, A. Humic and fulvic acids as biostimulants in horticulture. Sci. Hortic. 2015. [CrossRef]

(C) 2018 by the author. Licensee MDPI, Basel, Switzerland. This article is an open access article distributed under the terms and conditions of the Creative Commons Attribution (CC BY) license (http://creativecommons.org/licenses/by/4.0/). 